\title{
Engineered Three-Dimensional Tumor Models to Study Natural Killer Cell Suppression Supplemental Information
}

Madison N. Temples ${ }^{1}$, Isaac M. Adjei ${ }^{1}$, Phoebe M. Nimocks ${ }^{1}$, Julie Djeu ${ }^{2}$, and Blanka Sharma ${ }^{1}$

${ }^{1}$ J. Crayton Pruitt Department of Biomedical Engineering, University of Florida 1275 Center Drive Biomedical Sciences Building JG-56

P.O. Box 116131

Gainesville, Florida 32611-6131

${ }^{2}$ Department of Immunology, Moffitt Cancer Center

12902 Magnolia Drive MRC 4E

Tampa, Florida 33612-9497

\section{Contents}

Supplementary Methods S1

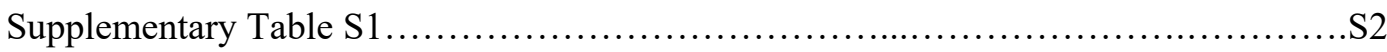

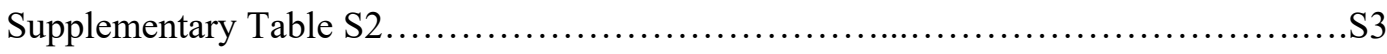

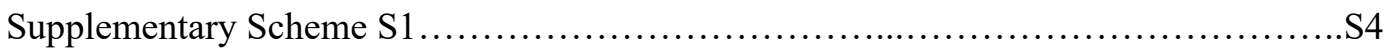

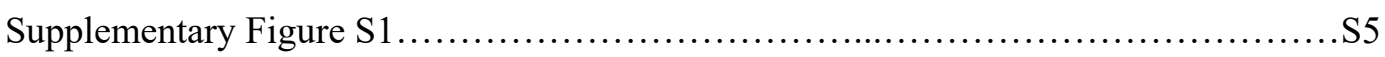

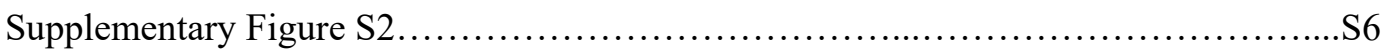

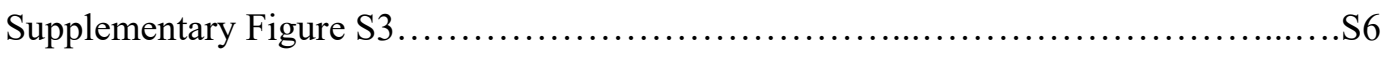

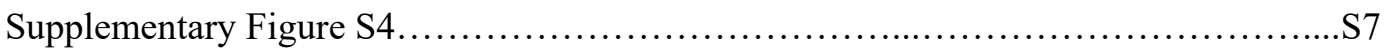

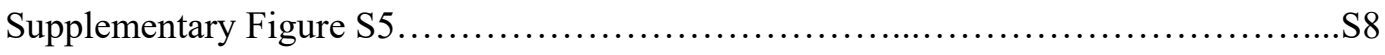

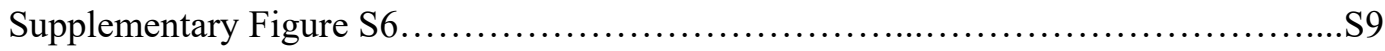

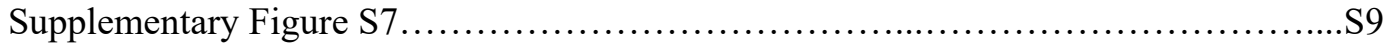

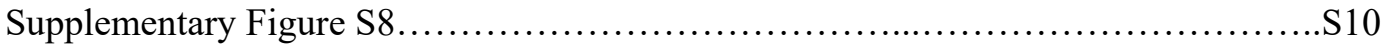

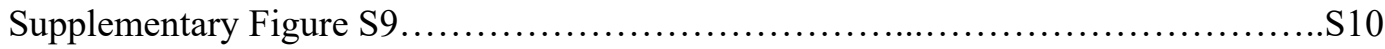

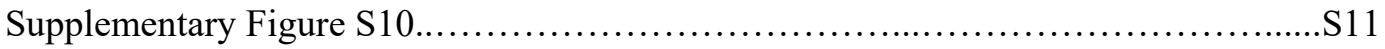

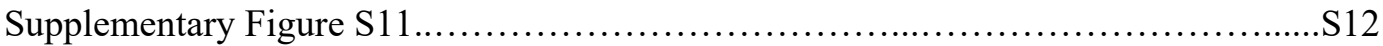

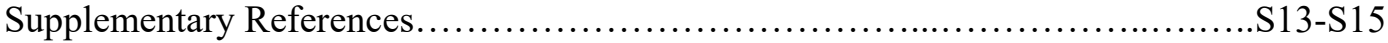




\section{Supplementary Methods.}

\section{Gene Expression of Xenograft Tumors:}

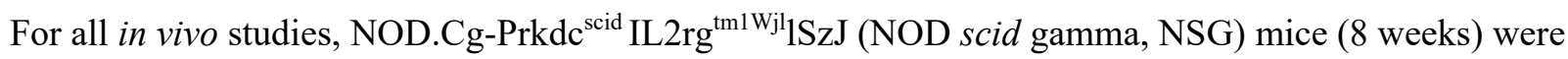
obtained from Jackson Laboratory (Bar Harbor, ME, USA) and were allowed to acclimate to the housing in the barrier facility at the University of Florida for at least one week prior to any injections. All procedures were performed in accordance with University of Florida Institutional Animal Care and Use Committee (IACUC).

Xenograft tumors were generated by injecting 1 million A549 or H1299 cells into 8-week-old NSG mice. Mice were anesthetized using isoflurane and tumor cells were injected into the left flank in $100 \mu \mathrm{L}$ of PBS:Matrigel (50:50 ratio) (Corning, NY, USA). Tumor growth was monitored every other day by calipers, and allowed to grow for 5/6 weeks, at which point mice were euthanized. The tumor was extracted and sectioned into $1 \mathrm{~mm}^{3}$ pieces, then placed into TRIzol®LS (Invitrogen Corp.) for 15 minutes on ice. The samples were centrifuges to pellet the tissue, and the supernatant was collected and allowed to come to room temperature. Chloroform was then added to the supernatant and the samples were shaken vigorously. The samples were then centrifuged, the aqueous phase was collected and added to the Qiashredder (Qiagen) according to manufacturer's instructions. RNA was extracted from the samples using RNeasy Mini Kit (Qiagen, Hilden, Germany) per manufacturer's instructions and converted to cDNA (iScript ${ }^{\mathrm{TM}}$ cDNA synthesis kit; Bio-Rad, Hercules, CA, USA), per manufacturer's instructions on the Mastercycler ${ }^{\circledR}$ nexus (Eppendorf, Hamburg, Germany). Quantitative RT-PCR was then performed on an Applied Biosystems ${ }^{\mathrm{TM}}$ QuantStudio ${ }^{\mathrm{TM}} 6$ Flex Real-Time PCR System (Applied Biosystems, Life Technologies, Carlsbad, CA, USA) using fast SYBR ${ }^{\text {TM }}$ green master mix (Applied Biosystems, Life Technologies, Carlsbad, CA, USA). Delta $\mathrm{C}_{\mathrm{T}}$ values were determined using the comparative $\mathrm{C}_{\mathrm{T}}$ method, normalized to GAPDH. The primer sequences for all soluble immunomodulatory target genes are listed in Supplementary Table S1 (Eurofins Genomics, Luxembourg City, Luxembourg). 
Supplementary Table S1. Primer Sequences for quantitative RT-PCR

\begin{tabular}{|c|c|c|c|}
\hline Gene & Forward primer $\left(5^{\prime} \rightarrow 3^{\prime}\right)$ & Reverse primer $\left(5^{\prime} \rightarrow 3^{\prime}\right)$ & Ref. \# \\
\hline MMP1 & AATGGAAAACACATGGTGTGA GTC C & TATCTAGGGTGACACCAGTGA CTG- & Ref $\#^{1}$ \\
\hline MMP2 & GAGGACTACGACCGCGGACAA & CCAAATGAACCGGTCCTTGA & Ref $\#^{2}$ \\
\hline MMP9 & TTGACAGCGACAAGTGG & CCTGATGTGGGTGAATACAA & Ref $\#^{2}$ \\
\hline MMP13 & TCCTACAAATCTCGCGGGAAT & GCATTTCTCGGAGCCTCTCA & Ref $\#^{3}$ \\
\hline MT1-MMP & GTGCCCTATGCCTACATCCG & TTGGGTATCCGTCCATCACT & Ref $\#^{4}$ \\
\hline MT2-MMP & CAG-CCCAGCCGCCATATGTC & CTTTCACTCGTACCCCGAAC & Ref $\#^{5}$ \\
\hline MT3-MMP & GGCTCGTGTGGGAAATGGTA & AGAACTCTTCCСССТCAAGTG & Ref $\#^{3}$ \\
\hline MT6-MMP & CATTTCTGTGGCTCTGCAGTGT & GAAGTGGCCCCTAAGTGACTCTA & Ref $\#^{3}$ \\
\hline$\alpha 4$ integrin & GAGGAATTCCCACCACTTCA & ATTTCATGGGCACAAAACC & Ref $\#^{6}$ \\
\hline$\alpha 5$ integrin & GCCTGTGGAGTACAAGTCCTT & AATTCGGGTGAAGTTATCTGTGG & Ref $\#^{7}$ \\
\hline$\alpha \mathrm{V}$ integrin & TGGGATTGTGGAAGGAG & AAATCCCTGTCCATCAGCAT & Ref $\#^{8}$ \\
\hline$\beta 1$ integrin & TTATTGGCCTTGCATTACTGCT & CCACAGTTGTTACGGCACTCT & Ref $\#^{7}$ \\
\hline$\beta 3$ integrin & TGCCTCAACAATGAGGTCATCCCT & AGACACATTGACCACAGAGGCACT & Ref $\#^{8}$ \\
\hline$\beta 5$ integrin & CAGGTTACATCGGGGACAAC & ACGCAATCTCTCTTGGTGCT & Ref $\#^{9}$ \\
\hline$\beta 7$ integrin & TGGTTTTGGTTCCTTTGTGGA & GGTGAAAGCTGAATGGTGACT & Ref $\#^{7}$ \\
\hline TGF- $\beta 1$ & GCCCTGGACACCAACTATTG & CGTGTCCAGGCTCCAAATG & Ref $\#^{10}$ \\
\hline TGF- $\beta 2$ & AAGCTTACACTGTCCCTGCTGC & TGTGGAGGTGCCATCAATACCT & Ref $\#^{10}$ \\
\hline TGF- $\beta 3$ & TCAGCCTCTCTCTGTCCACTT & CATCACCGTTGGCTCAGGG & $\operatorname{Ref} \#^{10}$ \\
\hline IL-6 & AATTCGGTACATCCTCGACGG & TGACCAGAAGAAGGAATGCCC & Ref $\#^{11}$ \\
\hline MCP-1 & TCTCGCCTCCAGCATGAAA & TCCTGAACCCACTTCTGCTTG & Ref $\#^{11}$ \\
\hline SDF-1 & ATGAACGCCAAGGTCGTGG & GGCTGTGCTTACTTGTTTAAAG & Ref $\#^{12}$ \\
\hline CX3CL1 & AACTCGAAATGGCGGCACCTT & ATGAATTACTACCACAGCTCCG & Ref $\#^{13}$ \\
\hline GAPDH & TAGACGGGAAGCTCACTGGC & AGGTCCACCACCCTGTTGCT & Ref $\#^{2}$ \\
\hline
\end{tabular}


Supplementary Table S2. Cytokine and Chemokines analyzed by ELISAs.

\begin{tabular}{|c|c|c|c|}
\hline Cytokine/Chemokine & Role in Cancer & $\begin{array}{c}\text { Primary } \\
\text { Production Source }\end{array}$ & Reference \\
\hline $\begin{array}{l}\text { Transforming Growth } \\
\text { Factor } \beta 1 \text { (TGF- } \beta 1)\end{array}$ & $\begin{array}{l}\text { An immunosuppressive growth factor; } \\
\text { promotes metastasis }\end{array}$ & Tumors & $\operatorname{Ref} \#^{14-16}$ \\
\hline Interleukin 6 (IL-6) & $\begin{array}{l}\text { A pleiotropic pro-inflammatory cytokine; } \\
\text { promotes angiogenesis; promotes } \\
\text { metastasis and cancer progression }\end{array}$ & $\begin{array}{l}\text { Tumors and } \\
\text { immune cells }\end{array}$ & $\operatorname{Ref} \#^{17-19}$ \\
\hline $\begin{array}{l}\text { Chemokine (C-X3-C } \\
\text { motif) ligand } 1 \text { (CX3CL1) }\end{array}$ & $\begin{array}{l}\text { A chemokine that recruits leukocytes; } \\
\text { promotes angiogenesis; increased with } \\
\text { increased tumor pathological state }\end{array}$ & Tumors & $\operatorname{Ref} \#^{20,21}$ \\
\hline $\begin{array}{l}\text { Monocyte chemoattractant } \\
\text { protein } 1(\mathrm{MCP}-1)\end{array}$ & $\begin{array}{l}\text { A pro-inflammatory chemokine that } \\
\text { recruits many immune cells; promotes } \\
\text { angiogenesis and tumor progression }\end{array}$ & $\begin{array}{l}\text { Tumors and } \\
\text { immune cells }\end{array}$ & $\operatorname{Ref} \#^{22}$ \\
\hline $\begin{array}{l}\text { Stromal Cell-Derived } \\
\text { Factor } 1 \alpha(\mathrm{SDF}-1 \alpha)\end{array}$ & $\begin{array}{c}\text { A leukocyte and stem cell homing } \\
\text { chemokine; has a role in invasion and } \\
\text { metastasis of tumor cells }\end{array}$ & Tumors & $\operatorname{Ref} \#^{1,23}$ \\
\hline $\begin{array}{l}\text { MHC Class I-Related } \\
\text { Sequence A (MICA) }\end{array}$ & $\begin{array}{l}\text { A stress-induced surface ligand on cancer } \\
\text { cells that binds to the activating receptors } \\
\text { (ex: NKG2D) on NK cells }\end{array}$ & Tumors & $\operatorname{Ref} \#^{24-26}$ \\
\hline $\begin{array}{l}\text { Regulated on Activation, } \\
\text { Normal T Cell Expressed } \\
\text { and Secreted (RANTES) }\end{array}$ & $\begin{array}{l}\text { A pro-inflammatory leukocyte trafficking } \\
\text { and homing chemokine }\end{array}$ & Immune cells & $\operatorname{Ref} \#^{27,28}$ \\
\hline Interferon $\gamma($ IFN- $\gamma)$ & A pleiotropic pro-inflammatory cytokine & Immune cells & $\operatorname{Ref} \#^{29-31}$ \\
\hline $\begin{array}{l}\text { Macrophage Inflammatory } \\
\text { Protein } 1 \alpha(\text { MIP-1 } \alpha)\end{array}$ & $\begin{array}{l}\text { A pro-inflammatory leukocyte trafficking } \\
\text { and homing chemokine }\end{array}$ & Immune cells & $\operatorname{Ref} \#^{32-34}$ \\
\hline $\begin{array}{l}\text { Macrophage Inflammatory } \\
\text { Protein } 1 \beta(\text { MIP-1 } \beta)\end{array}$ & $\begin{array}{c}\text { A pro-inflammatory leukocyte trafficking } \\
\text { and homing chemokine }\end{array}$ & Immune cells & $\operatorname{Ref} \#^{32-34}$ \\
\hline
\end{tabular}


Photocrosslink the first half of the PEG-based

precursor solutions

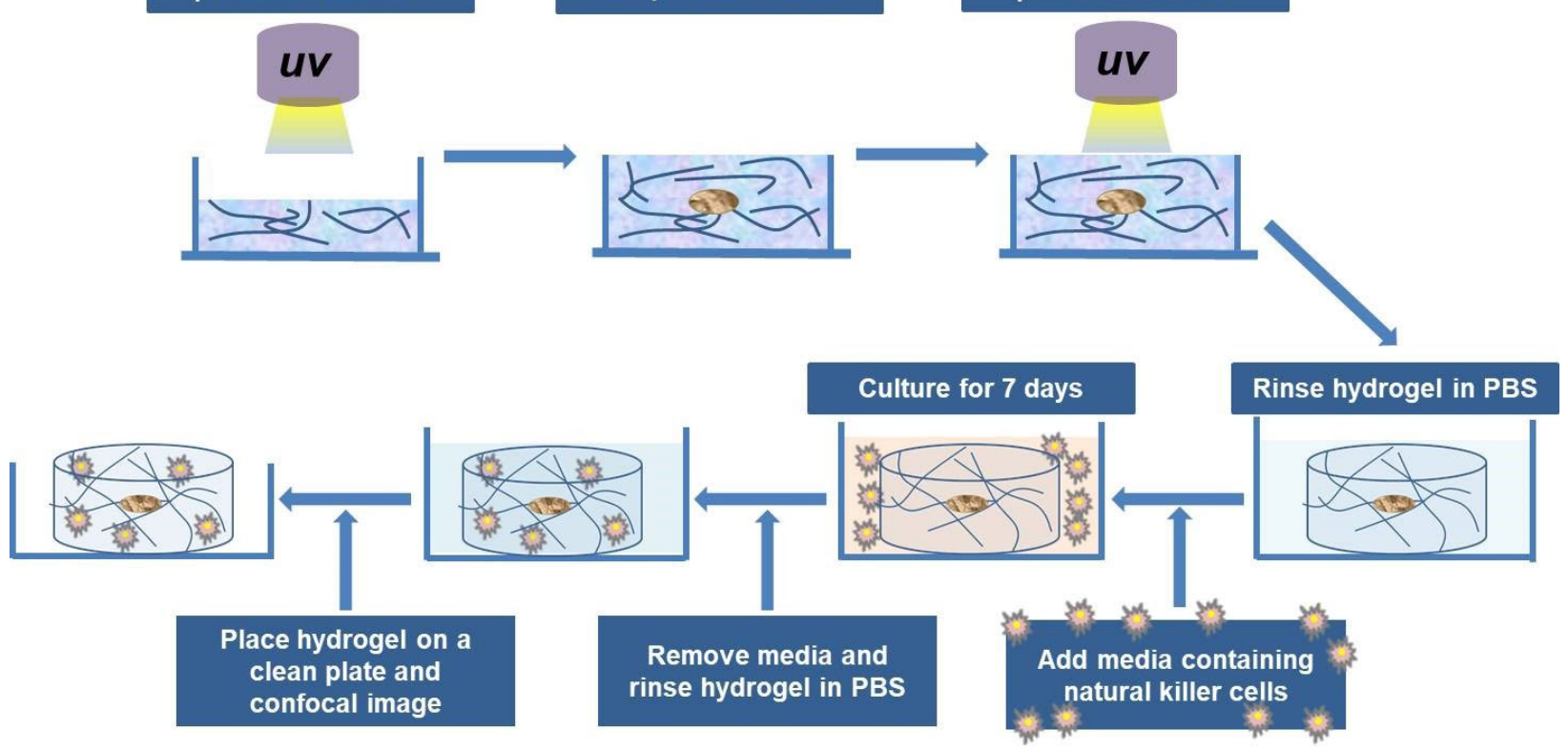

Supplementary Scheme S1: Experimental set up for NK-92 cell migration into the PEG-based hydrogels. Twenty five $\mu \mathrm{L}$ of the precursor solution is photopolymerized, then the $3 \mu \mathrm{L}$ fibrin clot containing $100 \mathrm{ng}$ of SDF- $1 \alpha$ is allowed to form on top of the half of the hydrogel. Then $25 \mu \mathrm{L}$ of the same precursor solution is added to the top of the gel/fibrin clot and photopolymerized. The hydrogel is then rinsed in PBS and 50,000 NK-92 cells suspended in media is added to the well containing the hydrogel. After 7 days of incubation on a shaker, the hydrogel is rinsed in PBS, placed on a new clean plate, and confocal imaged. 
A.

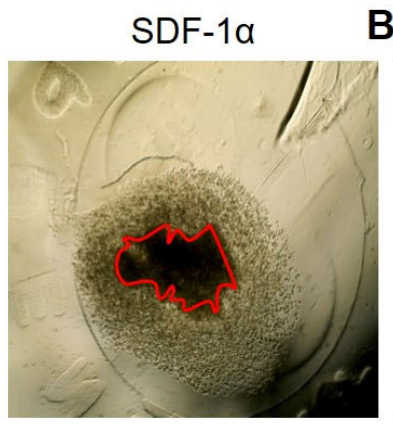

B. No SDF-1a

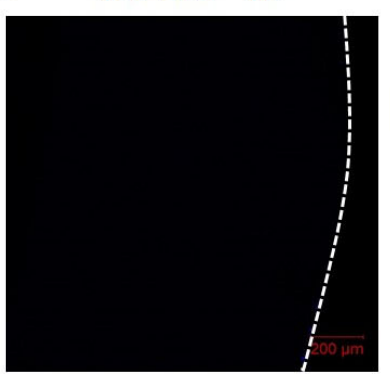

C. No fibrin clot or SDF-1 $\alpha$

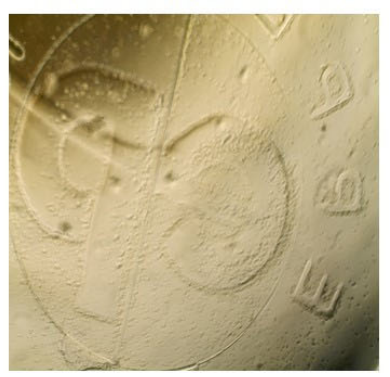

D. No fibrin clot or SDF-1a

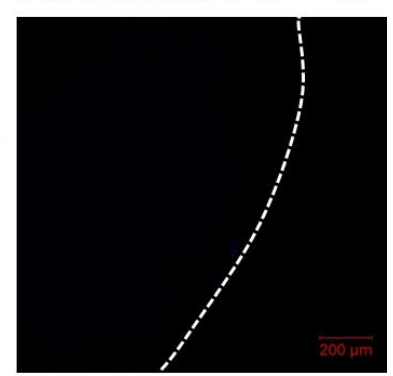

Supplementary Figure S1. NK-92 cell migration after 7 days of incubation into MMP degradable hydrogels with 5 mM RGD. NK-92 migration into hydrogels (A) with a point source of $100 \mathrm{ng}$ of SDF$1 \alpha$ outlined in red (brightfield image, 10x) after 7 days of incubation. With the inclusion of the SDF-1 $\alpha$ point source (outlined in red) the NK-92 cells migrate into the gel and surround the point source. (B) NK92 cells are unable to migrate into hydrogels containing the fibrin clot without the SDF- $1 \alpha$ (confocal image, 10x). The cells are also unable to migrate into hydrogels lacking both the clot and SDF-1 $\alpha$ demonstarted by the (C) brightfield image and (D) confocal image (10x for both). 


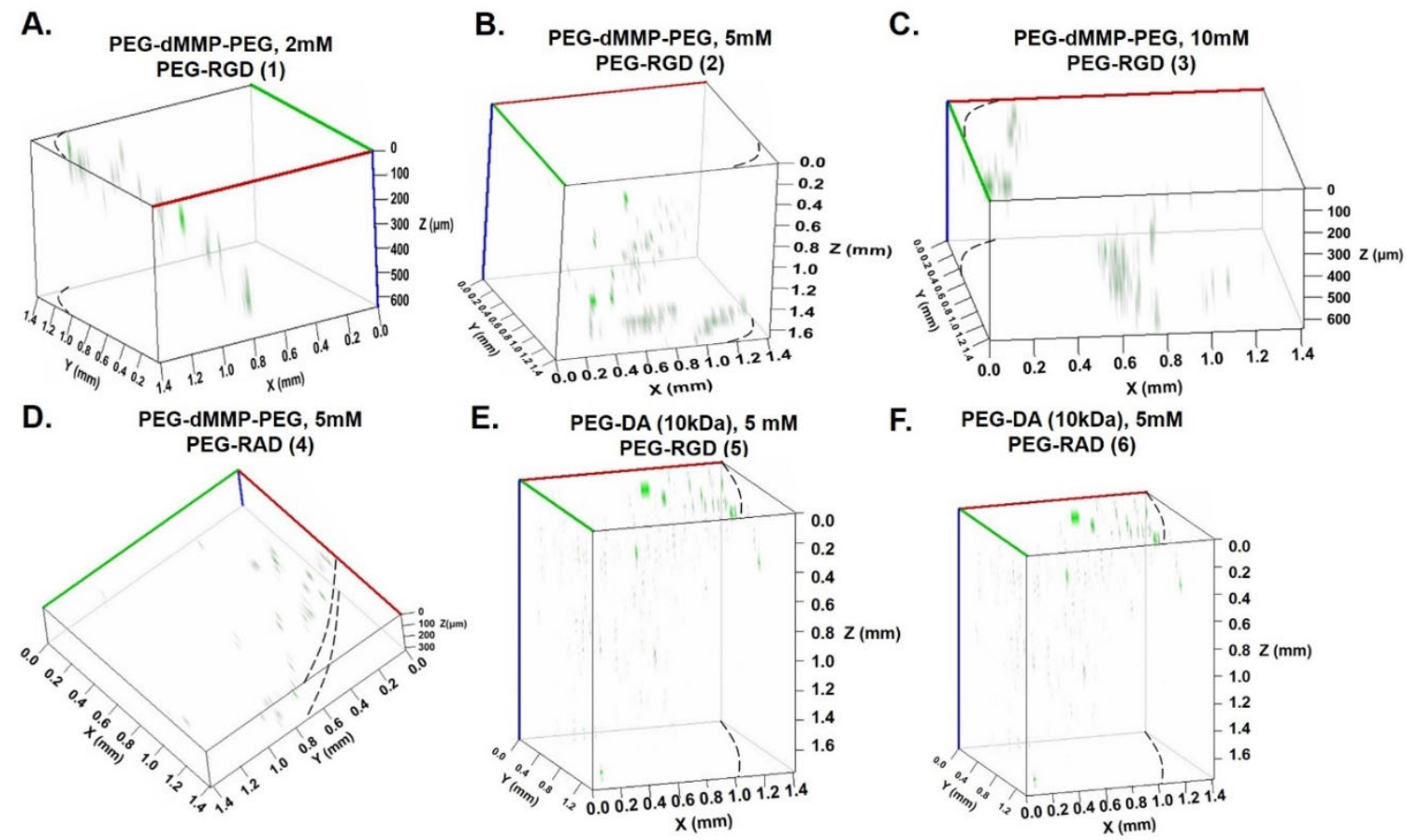

Supplementary Figure S2. 3D renderings of NK-92 cells migration into hydrogels of various compositions. 3D renderings of calcein AM (green) labeled NK-92 cells into (A) group 1: PEG-dMMPPEG and $2 \mathrm{mM}$ PEG-RGD, (B) group 2: PEG-dMMP-PEG, and 5mM PEG-RGD, (C) group 3: PEGdMMP-PEG, and 10 mM PEG-RGD, (D) group 4: PEG-dMMP-PEG, and 5 mM PEG-RAD, (E) group 5: PEG-DA (10kDa) and 5mM PEG-RGD, (F) group 6: PEG-DA (10kDa) and 5mM PEG-RAD hydrogels. PEG-RAD served as a negative control for PEG-RGD.

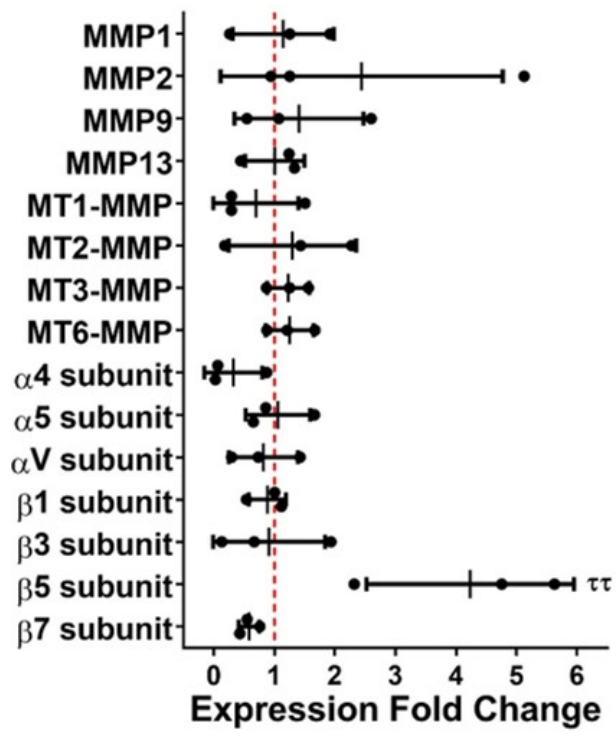

Supplementary Figure S3. MMP and integrin gene expression in NK-92 cells after SDF-1 $\alpha$ treatment. Fold change of gene expression for MMPs and integrins from SDF- $1 \alpha$ treated NK-92 cells relative to baseline $(n=3), \tau \tau$ denotes $P \leq 0.01$. 

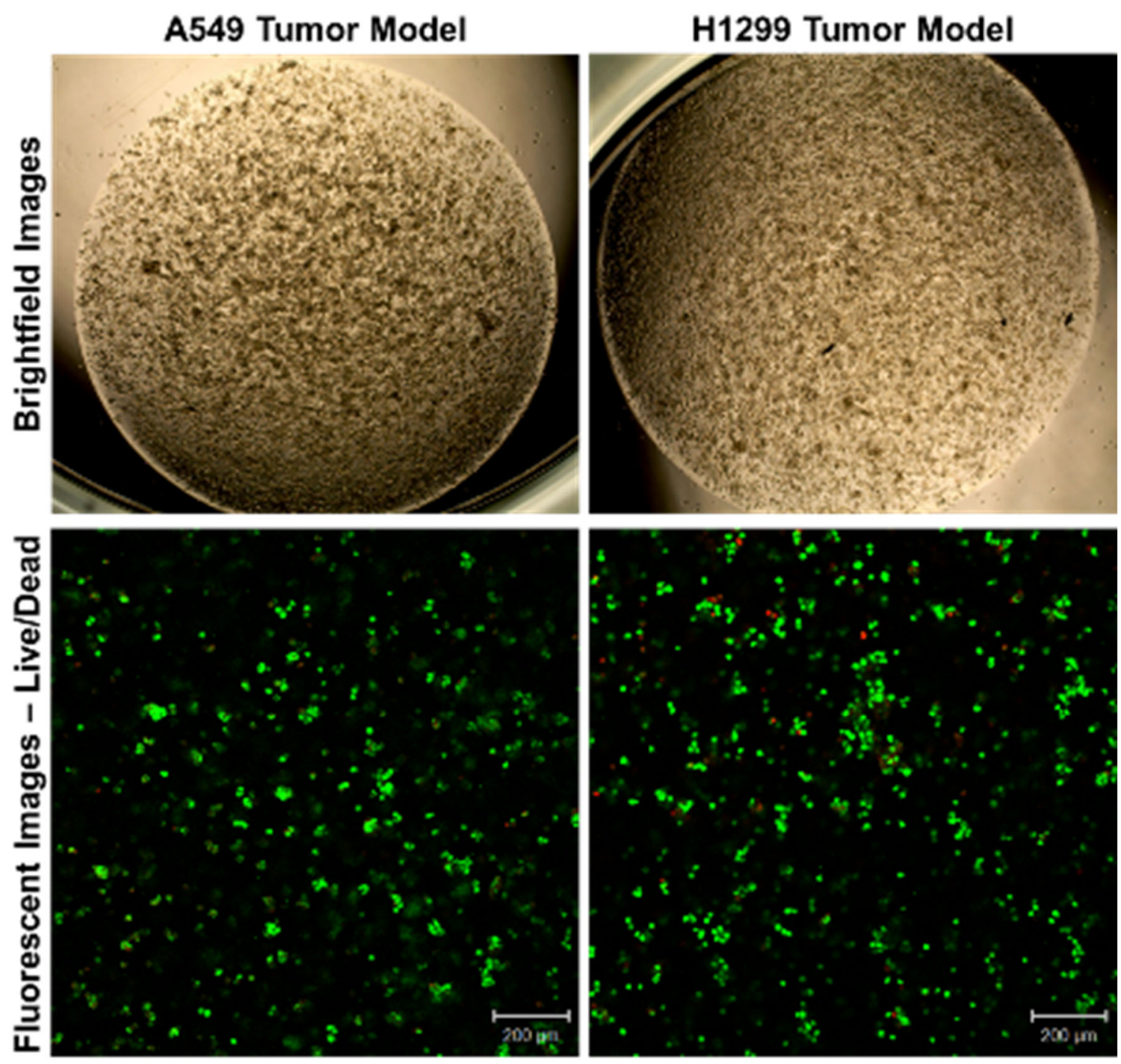

Supplementary Figure S4. Tumor models immediately after encapsulation of cancer cells.

Brightfield images, at 4x magnification, and live (green)-dead (red) stained A549 and H1299 cells in the tumor models after encapsulation of cells. 
A.

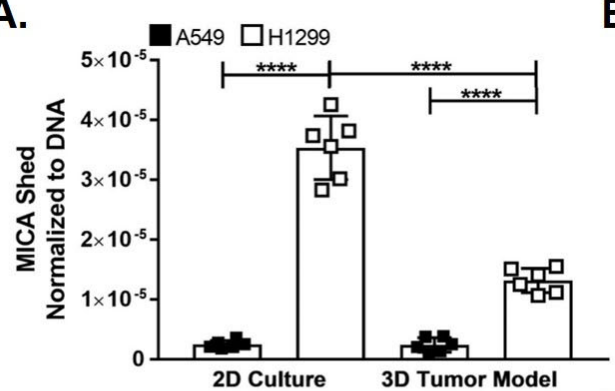

D.

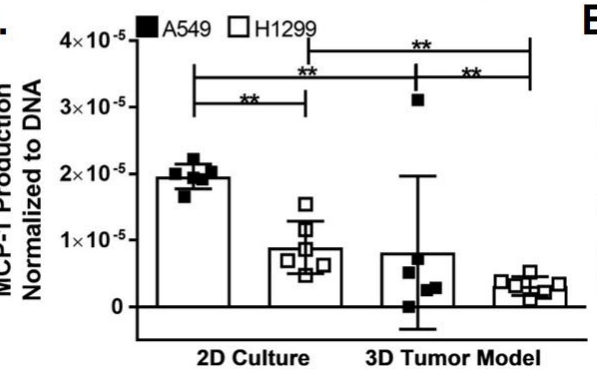

B.
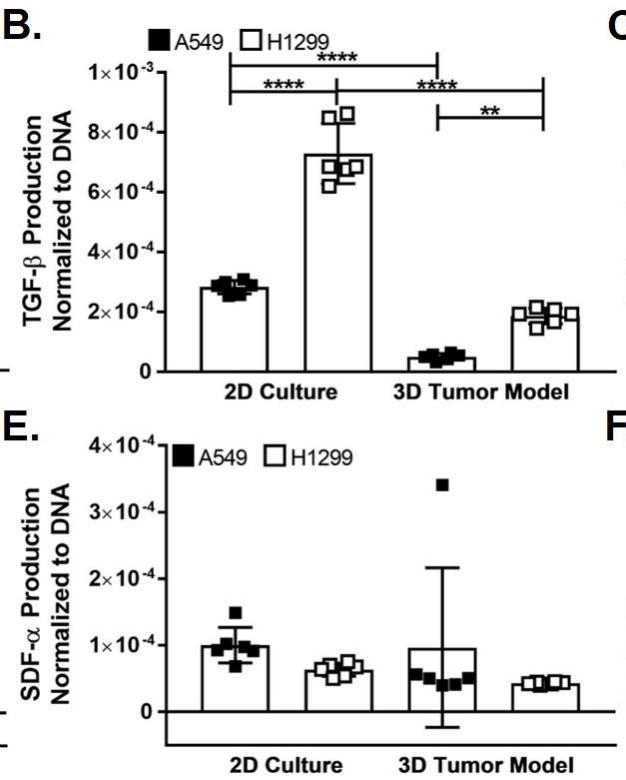

C.

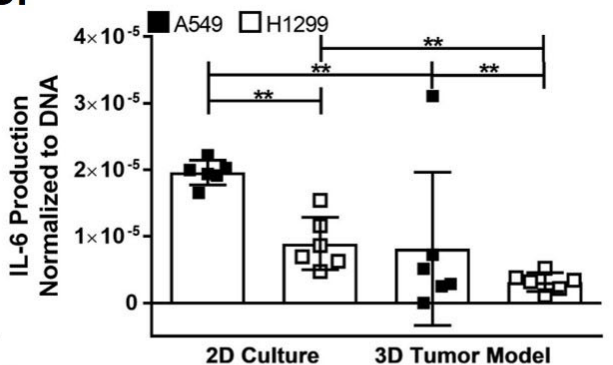

F.

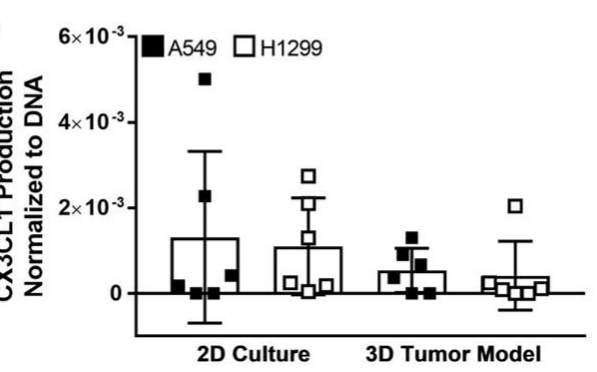

Supplementary Figure S5. Soluble immunomodulatory molecules produced by A549 and H1299 cells cultured in 2D monolayer culture and 3D tumor models. The concentration of (A) MICA, (B) TGF- $\beta$, (C) IL-6, (D) MCP-1, (E) SDF-1 $\alpha$, and (F) CXC3L1 in the media of the A549 and H1299 cells in $2 \mathrm{D}$ monolayer culture and the 3D tumor models normalized to the amount of DNA in the respective sample. $* *$ denotes $\mathrm{P} \leq 0.01$ and $* * * *$ denotes $\mathrm{P} \leq 0.0001$. 

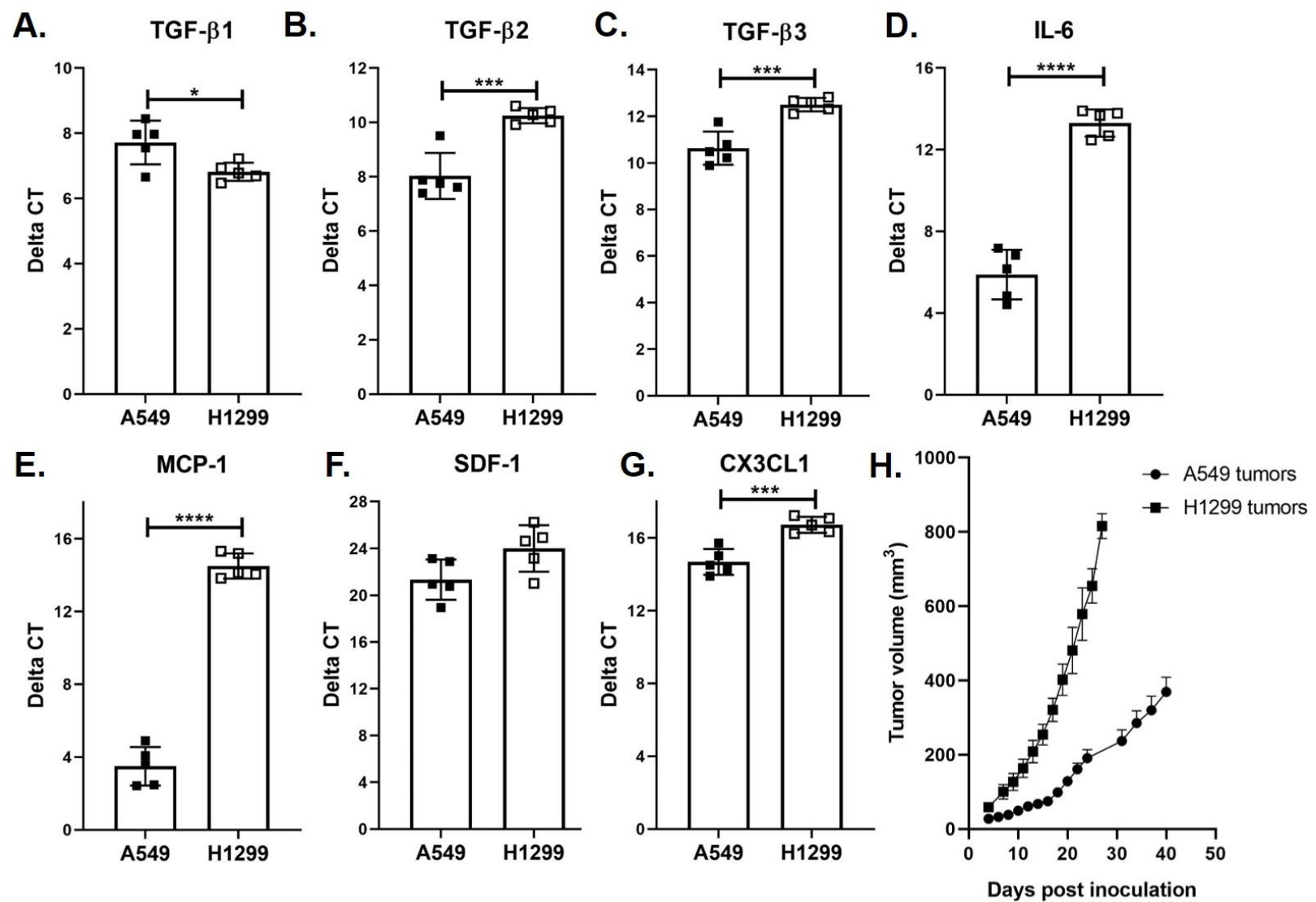

Supplementary Figure S6. Gene expression of soluble immunomodulatory molecules in A549 and H1299 xenograft tumors. Gene expression analysis of (A) TGF- $\beta 1$, (B) TGF- $\beta 2$, (C) TGF- $\beta 3$, (D) IL6, (E) MCP-1, (F) SDF-1, and (G) CXC3L1 from A549 and H1299 xenograft tumors in NSG mice (n=5). $*$ denotes $\mathrm{P} \leq 0.05, * * *$ denotes $\mathrm{P} \leq 0.001$ and $* * * *$ denotes $\mathrm{P} \leq 0.0001$. Growth curves for the xenograft tumors in the NSG mice.

A.
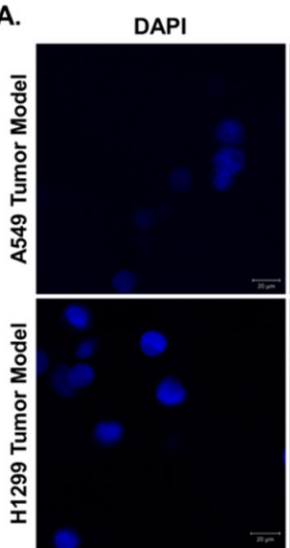

MICA

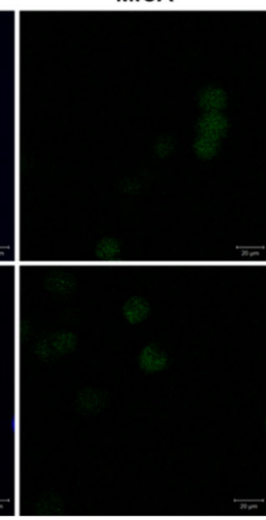

Merge
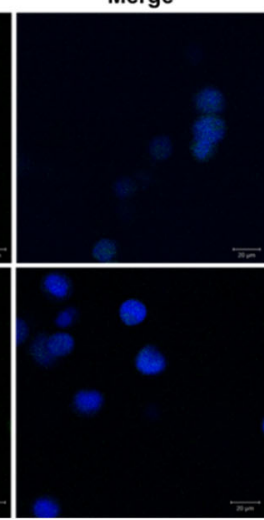

B.
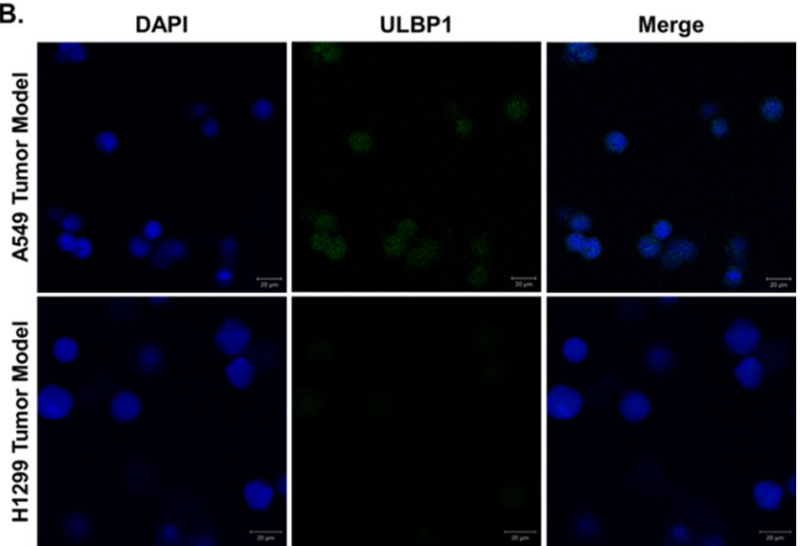

Supplementary Figure S7. Expression of stress-induced ligands of late stage tumor models. Representative immunofluorescent images for (A) MICA/B (green) and (B) ULBP1 (green) ligands on the cells in the late stage A549 and H1299 tumor models. The nucleus is stained with Hoechst (blue). 
A.

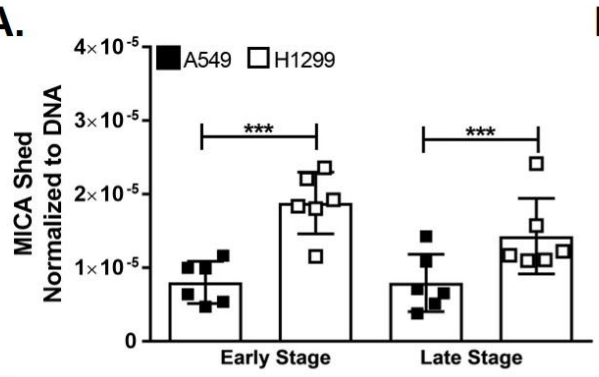

D.

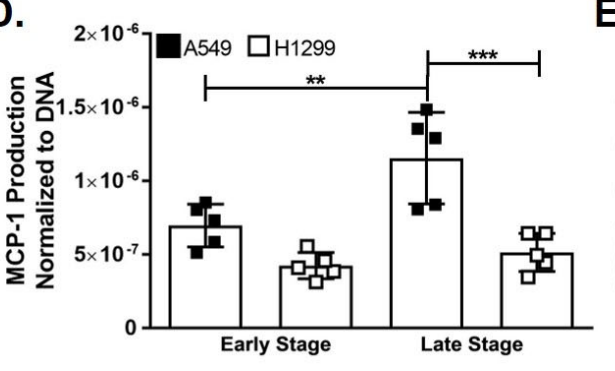

B.

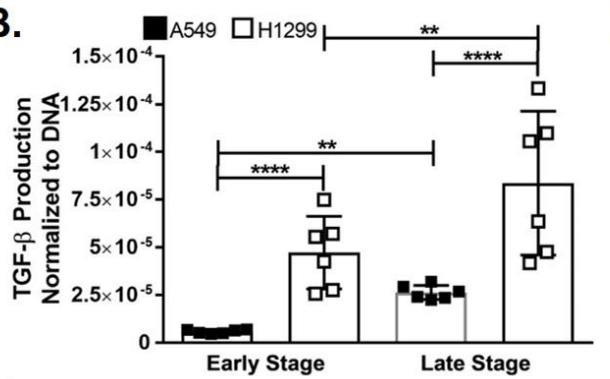

E.

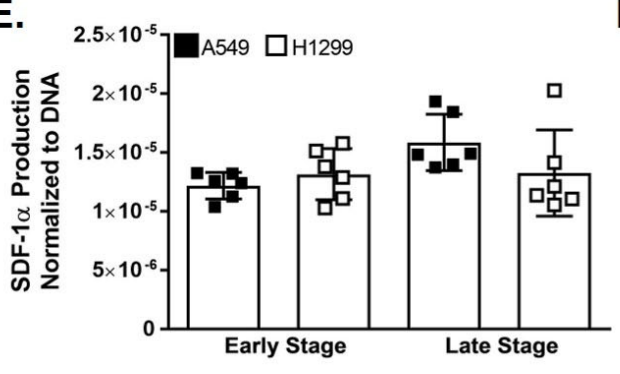

C.

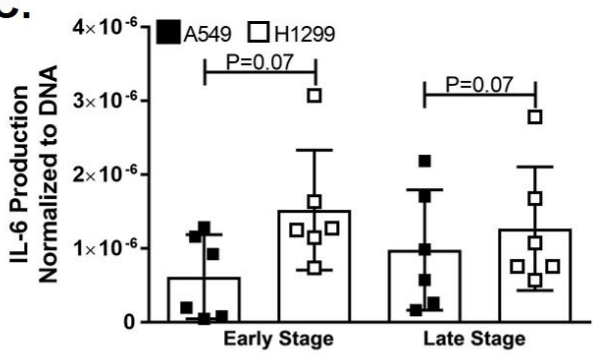

F.

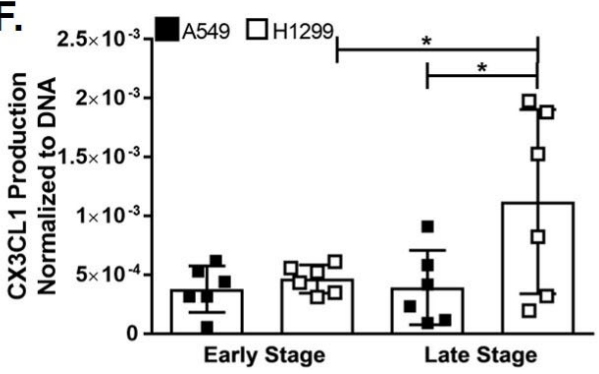

Supplementary Figure S8. Soluble immunomodulatory molecules produced by A549 and H1299 cells cultured in 3D tumor models normalized to total DNA. The concentration of (A) MICA, (B) TGF- $\beta$, (C) IL-6, (D) MCP-1, (E) SDF-1 $\alpha$, and (F) CXC3L1 in the media of the A549 and H1299 tumor models at the early and late stage normalized to the amount of DNA in the respective sample. ${ }^{*}$ denotes $\mathrm{P}$ $\leq 0.05, * *$ denotes $\mathrm{P} \leq 0.01$, *** denotes $\mathrm{P} \leq 0.001$, and $* * * *$ denotes $\mathrm{P} \leq 0.0001$.
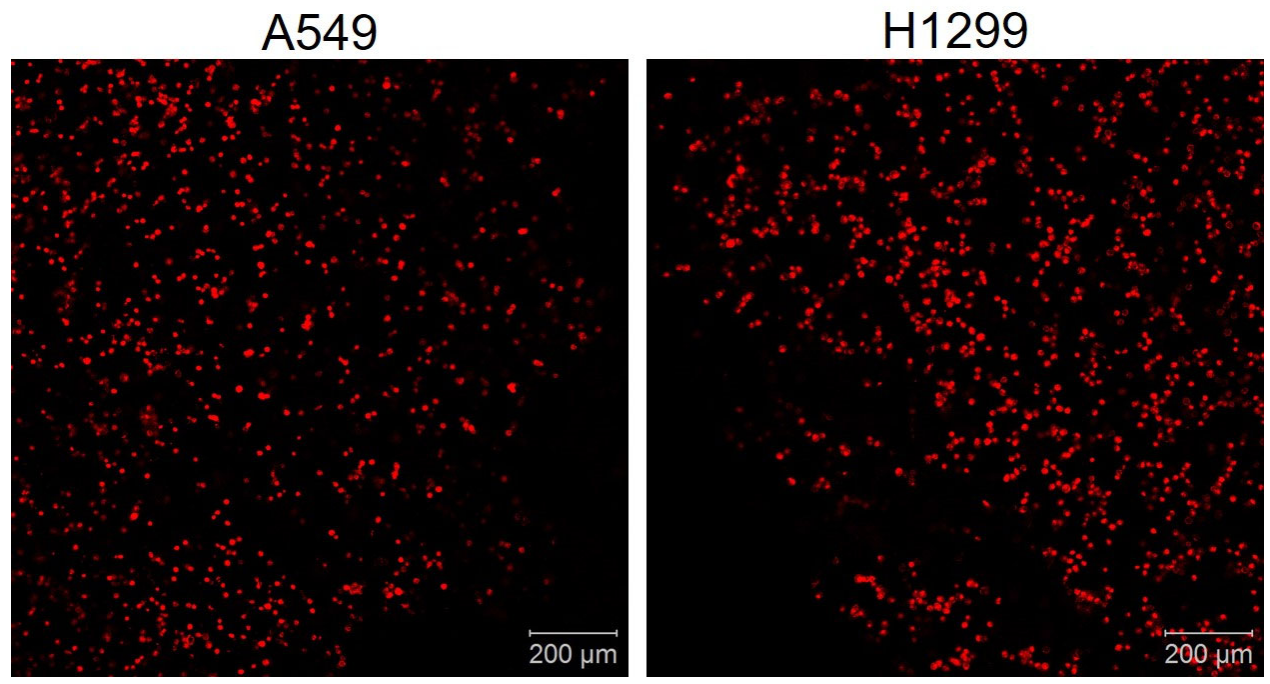

Supplementary Figure S9. Representative figure for control tumor models without NK-92 cell incubation. Representative immunofluorescent images for DiO (red) stained A549 and H1299 tumor models. 
A.

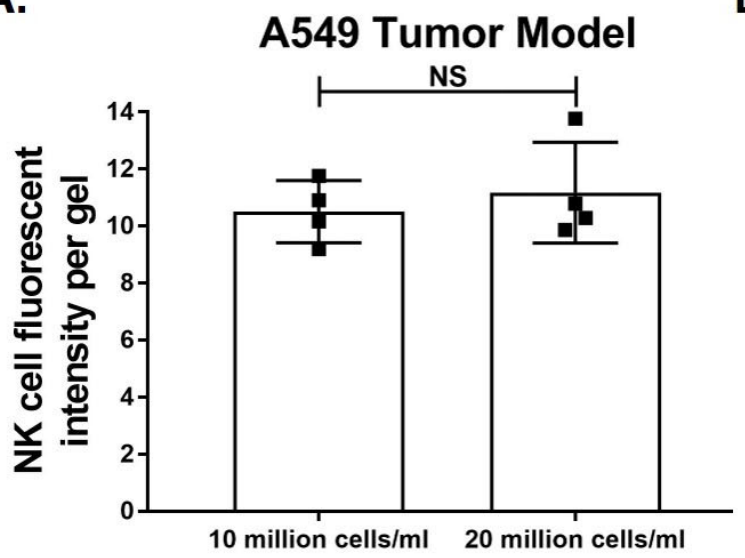

B.
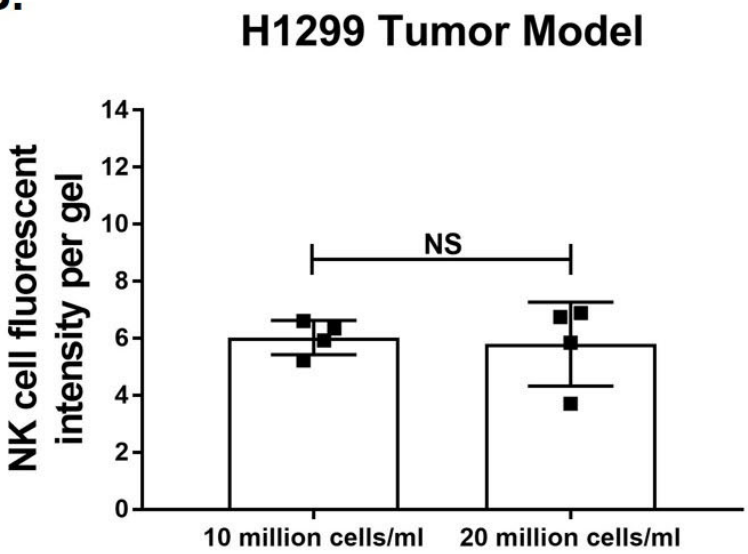

Supplementary Figure S10. Quantification of NK-92 cell migration into early stage tumor models of different cell densities. Fiji analysis of fluorescent intensity of the infiltrated NK-92 cells into the early stage (A) A549 tumor models and (B) H1299 tumor models at 10 million cells $/ \mathrm{ml}$ or 20 million cells $/ \mathrm{ml}$ $(n=3)$. The NK-92 cells were incubated with the tumor models at an E:T ratio of 0.5:1 for two hours, NS denotes no significance $(n=4)$. 
A.

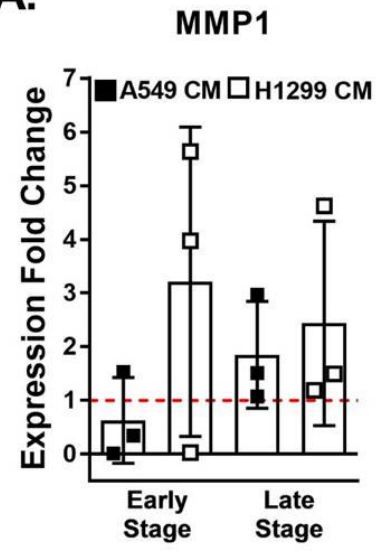

D.

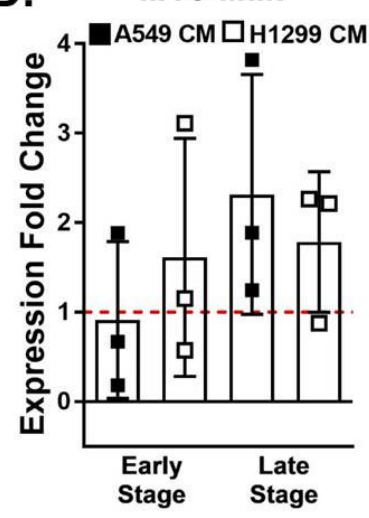

B.

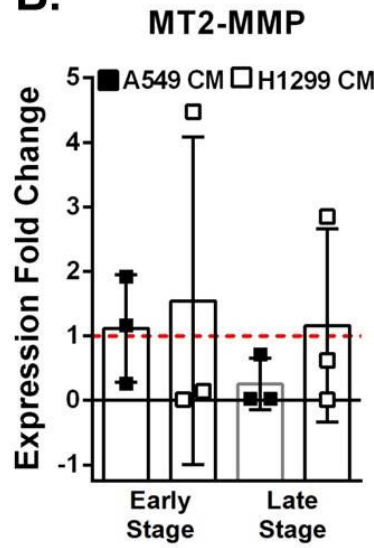

E.

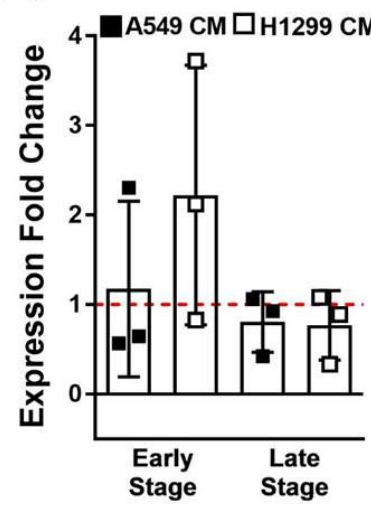

C.

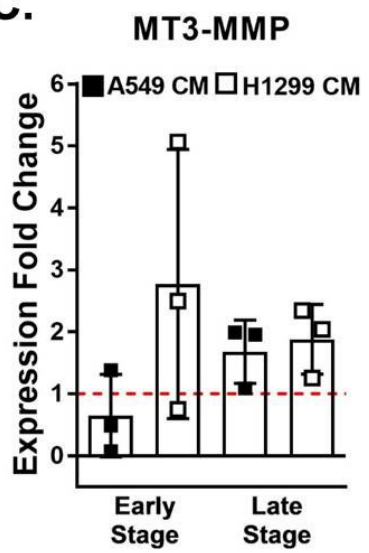

F.

$\beta 5$ subunit

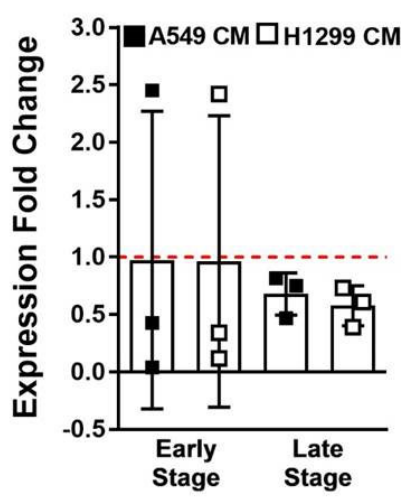

Supplementary Figure S11. Gene expression profiles of NK-92 cells incubated with conditioned media (CM) from the tumor models. Quantitative RT-PCR was performed to determine the expression fold change of (A) matrix metalloproteinase 1 (MMP1), (B) MT3-MMP, (C) MT6-MMP, (D) $\alpha$ V integrin subunit, and (E) $\beta 5$ integrin subunit from the RNA of NK-92 cells treated with conditioned media from the various tumor models $(n=3)$. Fold change compared to NK-92 cells in fresh coculture media, and the baseline is indicated by the red dotted line. For comparisons across groups and for comparison to baseline, no significance. 


\section{Supplementary References:}

(1) Goda, S.; Inoue, H.; Umehara, H.; Miyaji, M.; Nagano, Y.; Harakawa, N.; Imai, H.; Lee, P.; Macarthy, J. B.; Ikeo, T.; et al. Matrix Metalloproteinase-1 Produced by Human CXCL12Stimulated Natural Killer Cells. Am. J. Pathol. 2006, 169 (2), 445-458. https://doi.org/10.2353/ajpath.2006.050676.

(2) Edsparr, K.; Speetjens, F. M.; Mulder-Stapel, A.; Goldfarb, R. H.; Basse, P. H.; Lennernäs, B.; Kuppen, P. J. K.; Albertsson, P. Effects of IL-2 on MMP Expression in Freshly Isolated Human NK Cells and the IL-2-Independent NK Cell Line YT. J. Immunother. 2010, 33 (5), 475-481. https://doi.org/10.1097/CJI.0b013e3181d372a0.

(3) Edsparr, K.; Johansson, B. R.; Goldfarb, R. H.; Basse, P. H.; Nannmark, U.; Speetjens, F. M.; Kuppen, P. J. K.; Lennernäs, B.; Albertsson, P. Human NK Cell Lines Migrate Differentially in Vitro Related to Matrix Interaction and MMP Expression. Immunol. Cell Biol. 2009, 87 (6), 489495. https://doi.org/10.1038/icb.2009.35.

(4) Chuang, S. S.; Kim, M. H.; Johnson, L. A.; Albertsson, P.; Kitson, R. P.; Nannmark, U.; Goldfarb, R. H.; Mathew, P. A. 2B4 Stimulation of YT Cells Induces Natural Killer Cell Cytolytic Function and Invasiveness. Immunology 2000, 100 (3), 378-383. https://doi.org/10.1046/J.13652567.2000.00031.X.

(5) Nakada, M.; Nakamura, H.; Ikeda, E.; Fujimoto, N.; Yamashita, J.; Sato, H.; Seiki, M.; Okada, Y. Expression and Tissue Localization of Membrane-Type 1, 2, and 3 Matrix Metalloproteinases in Human Astrocytic Tumors. Am. J. Pathol. 1999, 154 (2), 417-428. https://doi.org/10.1016/S00029440(10)65288-1.

(6) Hirakawa, S.; Hong, Y.-K.; Harvey, N.; Schacht, V.; Matsuda, K.; Libermann, T.; Detmar, M. Identification of Vascular Lineage-Specific Genes by Transcriptional Profiling of Isolated Blood Vascular and Lymphatic Endothelial Cells. Am. J. Pathol. 2003, 162 (2), 575-586. https://doi.org/10.1016/S0002-9440(10)63851-5.

(7) LaPointe, V. L. S.; Verpoorte, A.; Stevens, M. M. The Changing Integrin Expression and a Role for Integrin B8 in the Chondrogenic Differentiation of Mesenchymal Stem Cells. PLoS One 2013, 8 (11), e82035. https://doi.org/10.1371/journal.pone.0082035.

(8) Meng, R.; Tang, H.-Y.; Westfall, J.; London, D.; Cao, J. H.; Mousa, S. A.; Luidens, M.; Hercbergs, A.; Davis, F. B.; Davis, P. J.; et al. Crosstalk between Integrin Av $\beta 3$ and Estrogen Receptor- $\alpha$ Is Involved in Thyroid Hormone-Induced Proliferation in Human Lung Carcinoma Cells. PLoS One 2011, 6 (11), e27547. https://doi.org/10.1371/journal.pone.0027547.

(9) Chen, J.; Green, J.; Yurdagul, A.; Albert, P.; Mcinnis, M. C.; Orr, A. W. Avß3 Integrins Mediate Flow-Induced NF-KB Activation, Proinflammatory Gene Expression, and Early Atherogenic Inflammation. Am. J. Pathol. 2015, 185, 2575-2589. https://doi.org/10.1016/j.ajpath.2015.05.013.

(10) Ventura, E.; Weller, M.; Macnair, W.; Eschbach, K.; Beisel, C.; Cordazzo, C.; Claassen, M.; Zardi, L.; Burghardt, I. TGF- $\beta$ Induces Oncofetal Fibronectin That, in Turn, Modulates TGF- $\beta$ Superfamily Signaling in Endothelial Cells. J. Cell Sci. 2018, 131 (1). https://doi.org/10.1242/jcs.209619.

(11) Yamagami, H.; Yamagami, S.; Inoki, T.; Amano, S.; Miyata, K. The Effects of Proinflammatory Cytokines on Cytokine-Chemokine Gene Expression Profiles in the Human Corneal Endothelium. Investig. Ophthalmol. Vis. Sci. 2003, 44 (2), 514-520. https://doi.org/10.1167/iovs.02-0498. 
(12) Ilhan, A.; Nabokikh, A.; Maj, M.; Vidakovic, M.; Nielsen, J. H.; Prikoszovich, T.; Niederle, B.; Base, W.; Luger, A.; Wagner, L. CXCL12/SDF-1 over-Expression in Human Insulinomas and Its Biological Relevance. Mol. Cell. Endocrinol. 2009, 298 (1-2), 1-10.

https://doi.org/10.1016/j.mce.2008.10.015.

(13) Sukkar, M. B.; Issa, R.; Xie, S.; Oltmanns, U.; Newton, R.; Kian, F. C. Fractalkine/CX3CL1 Production by Human Airway Smooth Muscle Cells: Induction by IFN- $\gamma$ and TNF- $\alpha$ and Regulation by TGF- $\beta$ and Corticosteroids. Am. J. Physiol. - Lung Cell. Mol. Physiol. 2004, 287 (6 31-6), L1230-40. https://doi.org/10.1152/ajplung.00014.2004.

(14) Huang, A.-L.; Liu, S.-G.; Qi, W.-J.; Zhao, Y.-F.; Li, Y.-M.; Lei, B.; Sheng, W.-J.; Shen, H. TGFB1 Protein Expression in Non-Small Cell Lung Cancers Is Correlated with Prognosis. Asian Pac. J. Cancer Prev. 2014, 15 (19), 8143-8147.

(15) Donatelli, S. S.; Zhou, J.-M.; Gilvary, D. L.; Eksioglu, E. A.; Chen, X.; Cress, W. D.; Haura, E. B.; Schabath, M. B.; Coppola, D.; Wei, S.; et al. TGF--Inducible MicroRNA-183 Silences TumorAssociated Natural Killer Cells. Proc. Natl. Acad. Sci. 2014, 111 (11), 4203-4208. https://doi.org/10.1073/pnas.1319269111.

(16) Ikushima, H.; Miyazono, K. TGF $\beta$ Signalling: A Complex Web in Cancer Progression. Nat. Rev. Cancer 2010, 10 (6), 415-424. https://doi.org/10.1038/nrc2853.

(17) Kumari, N.; Dwarakanath, B. S.; Das, A.; Bhatt, A. N. Role of Interleukin-6 in Cancer Progression and Therapeutic Resistance. Tumor Biol. 2016, 37 (9), 11553-11572. https://doi.org/10.1007/s13277-016-5098-7.

(18) Lee, S. O.; Yang, X.; Duan, S.; Tsai, Y.; Strojny, L. R.; Keng, P.; Chen, Y. IL-6 Promotes Growth and Epithelial-Mesenchymal Transition of CD133+ Cells of Non-Small Cell Lung Cancer. Oncotarget 2016, 7 (6), 6626-6638. https://doi.org/10.18632/oncotarget.6570.

(19) Qu, Z.; Sun, F.; Zhou, J.; Li, L.; Shapiro, S. D.; Xiao, G. Interleukin-6 Prevents the Initiation but Enhances the Progression of Lung Cancer. Cancer Res. 2015, 75 (16), 3209-3215. https://doi.org/10.1158/0008-5472.CAN-14-3042.

(20) Zhou, B.; Xu, H.; Ni, K.; Ni, X.; Shen, J. Expression of Chemokine XCL2 and CX3CL1 in Lung Cancer. Med. Sci. Monit. 2016, 22, 1560-1565. https://doi.org/10.12659/MSM.895985.

(21) Su, Y.-C.; Chang, H.; Sun, S.-J.; Liao, C.-Y.; Wang, L.-Y.; Ko, J.-L.; Chang, J. T. Differential Impact of CX3CL1 on Lung Cancer Prognosis in Smokers and Non-Smokers. Mol. Carcinog. 2018. https://doi.org/10.1002/mc.22787.

(22) Yoshimura, T. The Chemokine MCP-1 (CCL2) in the Host Interaction with Cancer: A Foe or Ally? Nat. Publ. Gr. 2018. https://doi.org/10.1038/cmi.2017.135.

(23) Kryczek, I.; Wei, S.; Keller, E.; Liu, R.; Zou, W. Stroma-Derived Factor (SDF-1/CXCL12) and Human Tumor Pathogenesis. Am. J. Physiol. Physiol. 2007, 292 (3), C987-C995. https://doi.org/10.1152/ajpcell.00406.2006.

(24) Konjević, G.; Vuletić, A.; Martinović, K. M.; Džodić, R. The Role of Activating and Inhibitory NK Cell Receptors in Antitumor Immune Response. Nat. Kill. Cells 2017. https://doi.org/10.5772/intechopen.69729.

(25) Roda-Navarro, P.; Vales-Gomez, M.; Chisholm, S. E.; Reyburn, H. T. Transfer of NKG2D and 
MICB at the Cytotoxic NK Cell Immune Synapse Correlates with a Reduction in NK Cell Cytotoxic Function. Proc. Natl. Acad. Sci. U. S. A. 2006, 103 (30), 11258-11263.

https://doi.org/10.1073/pnas.0600721103.

(26) Groh, V.; Wu, J.; Yee, C.; Spies, T. Tumour-Derived Soluble MIC Ligands Impair Expression of NKG2D and T-Cell Activation. Nature 2002, 419 (6908), 734-738.

https://doi.org/10.1038/nature01112.

(27) Roda, J. M.; Parihar, R.; Magro, C.; Nuovo, G. J.; Tridandapani, S.; Carson, W. E. Natural Killer Cells Produce T Cell-Recruiting Chemokines in Response to Antibody-Coated Tumor Cells. Cancer Res. 2006, 66 (1), 517-526. https://doi.org/10.1158/0008-5472.CAN-05-2429.

(28) Moretta, L.; Montaldo, E.; Vacca, P.; Del Zotto, G.; Moretta, F.; Merli, P.; Locatelli, F.; Mingari, M. C. Human Natural Killer Cells: Origin, Receptors, Function, and Clinical Applications. Int. Arch. Allergy Immunol. 2014, 164 (4), 253-264. https://doi.org/10.1159/000365632.

(29) Lin, C.-F.; Lin, C.-M.; Lee, K.-Y.; Wu, S.-Y.; Feng, P.-H.; Chen, K.-Y.; Chuang, H.-C.; Chen, C.L.; Wang, Y.-C.; Tseng, P.-C.; et al. Escape from IFN- $\gamma$-Dependent Immunosurveillance in Tumorigenesis. J. Biomed. Sci. 2017, 24 (1), 10. https://doi.org/10.1186/s12929-017-0317-0.

(30) Ikeda, H.; Old, L. J.; Schreiber, R. D. The Roles of IFN $\gamma$ in Protection against Tumor Development and Cancer Immunoediting. Cytokine Growth Factor Rev. 2002, 13 (2), 95-109. https://doi.org/10.1016/S1359-6101(01)00038-7.

(31) Hasmim, M.; Messai, Y.; Ziani, L.; Thiery, J.; Bouhris, J. H.; Noman, M. Z.; Chouaib, S. Critical Role of Tumor Microenvironment in Shaping NK Cell Functions: Implication of Hypoxic Stress. Front. Immunol. 2015, 6 (SEP), 1-9. https://doi.org/10.3389/fimmu.2015.00482.

(32) Menten, P.; Wuyts, A.; Van Damme, J. Macrophage Inflammatory Protein-1. Cytokine Growth Factor Rev. 2002, 13 (6), 455-481. https://doi.org/10.1016/S1359-6101(02)00045-X.

(33) O’Grady, N. P.; Tropea, M.; Preas II, H. L.; Reda, D.; Vandivier, R. W.; Banks, S. M.; Suffredini, A. F. Detection of Macrophage Inflammatory Protein (MIP)-1 $\alpha$ and MIP-1 $\beta$ during Experimental Endotoxemia and Human Sepsis. J. Infect. Dis. 1999, 179 (1), 136-141. https://doi.org/10.1086/314559.

(34) Dorner, B. G.; Scheffold, A.; Rolph, M. S.; Hü Ser, M. B.; Kaufmann, S. H. E.; Radbruch, A.; Flesch, I. E. A.; Kroczek, R. A. MIP-1a, MIP-1B, RANTES, and ATAC/Lymphotactin Function Together with IFN-y as Type 1 Cytokines. PNAS 2002, 99 (9), 6181-6186. 